\title{
Evaluation of Tidal Swampland Suitability Based on GIS Spatial Model on Barambai Reclamation Unit, South Kalimantan
}

\author{
Rony Riduan ${ }^{1, *}$, Sasmalini ${ }^{2}$, Hafiizh Prasetia ${ }^{1,}$ and Nova Annisa ${ }^{1}$ \\ ${ }^{1}$ Department of Environmental Engineering, Engineering Faculty, Lambung Mangkurat University \\ ${ }^{2}$ Postgraduate Program of Civil Engineering, Engineering Faculty, Lambung Mangkurat University
}

\begin{abstract}
Barambai reclamation unit in Barito Kuala regency, South Kalimantan, has great potential for tidal swampland agricultural development. Therefore, agricultural land suitability information is required. Evaluation of Barambai agricultural land suitability is conducted using Quantum GIS (Geographic Information System) software on land unit categories data (pyrites, cation exchange capacity, ash content value, salinity, hydrotopographic zone, and drainability). Identification and analysis results indicated that soil fertility is low to moderate, the $\mathrm{pH}$ of the soil is acid to very acid, and relatively high pyrite hazards. Agricultural land suitability in Barambai tidal swampland reclamation unit is most suitable for paddy plant (S1 and S2 criteria).
\end{abstract}

\section{Introduction}

Tidal swampland in Indonesia, especially South Kalimantan province has the great agricultural potential. Tidal swampland area in Indonesia is estimated at 20.11 million hectares composed of 2.07 million hectares of potential tidal land, 6.71 million hectares of land, 10.89 million hectares sulphate peat, and 0.44 million hectares of saline land. Barito Kuala regency in South Kalimantan province consists of tidal swamp area 96.07\% (287,992 hectares), while the $3.93 \%$ (11,774 hectares) is inland swamp [1].

Evaluation of land suitability for agricultural optimation in Barambai reclamation unit is using Geographic Information System (GIS) tools. The advantages of this tools are easy for data updating, data coordinates can be addressed clearly, and can be overlaid with other spatial themes. Utilization of GIS technology is expected to acquire detailed information about existing conditions, water management zone, and tidal swampland agricultural suitability. This information is expected to be used for appropriate land management recommendations.

\footnotetext{
* Corresponding author: ronyrdn@ulm.ac.id
} 


\section{Material and Methods}

\subsection{Study Area}

Soil samples were collected from five locations (Fig. 1) located in Barambai reclamation unit in South Kalimantan province. Soil sampling location i.e., sample 1 is located at the "Kolam Kiri Dalam" village with coordinates x, y (243246, 9667930); Sample 2 is located at the "Kolam Kiri" village with coordinates x, y (243246, 9667930); Sample 3 is located at the "Kolam Kiri" village with coordinates x, y (240058, 9662048); Sample 4 is located at the "Kolam Kiri Dalam" village with coordinates x, y $(242116,96692946)$; and 5 Samples are located at the "Karya Tani" village with coordinates x, y $(239256,9673946)$.
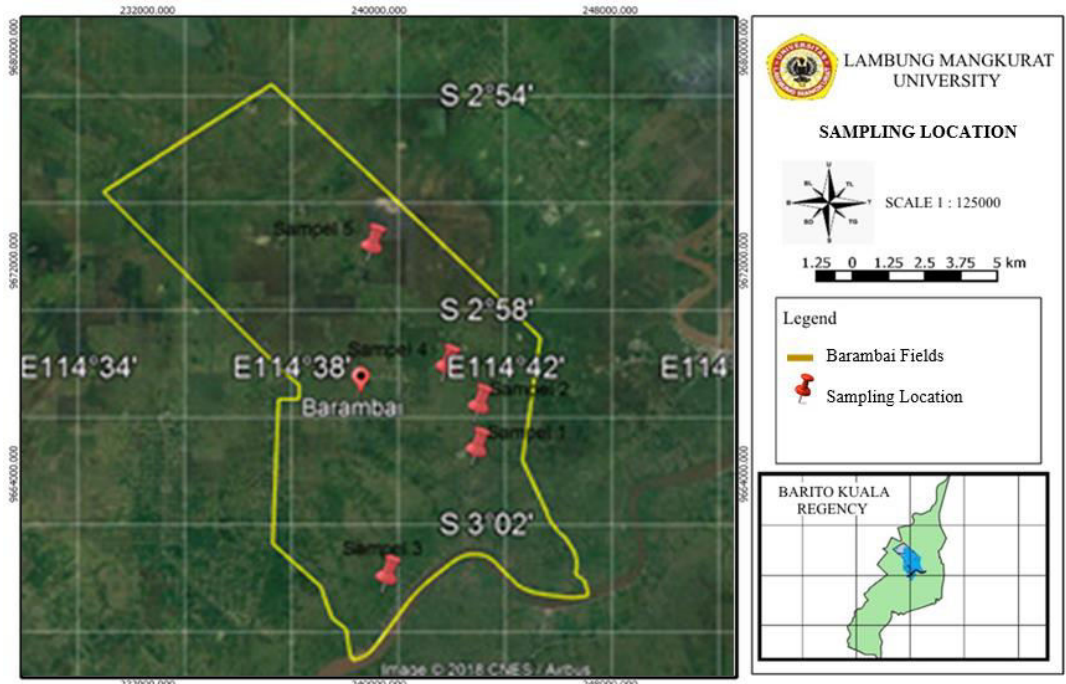

Fig. 1. Sampling Location

\subsection{Digital Image Process}

Data processing and analysis were conducted using QGIS Chugiak software 2.4.0. After the digitation process, other data that has been obtained is classified in the next attribute and database. Each variable of land unit category (pyrites, cation exchange capacity, ash content value, salinity, hydrotopographic zone, and drainability) are overlaid to get a new spatial data to produce the recommendation maps of the tidal swamp agricultural suitability [2] on Barambai reclamation unit.

\subsection{Data Collection}

Field testing is conducted with the implementation of hand-boring by using screw-type Auger drill, diameter $10 \mathrm{~cm}$ is equipped with the original soil samples in the form of thin steel tube with a diameter of $7 \mathrm{~cm}$ and a length of $40 \mathrm{~cm}$. Loose soil conditions where soil samples cannot be taken with the ordinary tube, will be equipped with a valve. Disturbed samples were taken using a thin wall tube or Shelby tube with an internal diameter of 70 $\mathrm{mm}$ will be pressed on the ground. Analysis of the observed soil fertility includes soil physical properties, cation exchange capacity, ash content value, $\mathrm{pH}$, temperature, conductivity, and salinity. Soil samples test is conducted in the laboratory with standard test procedure [3]. 


\subsection{Land Suitability Analysis Method On The QGIS}

QGIS analysis is conducted to get the value of land and water management zone, by using a query that refers to the provisions contained in the ISDP 1996 through field calculator on the QGIS.

\section{Results and Discussion}

\subsection{Suitability Indicators}

Land suitability classification of land use based on suitability for the specific purpose. The first stage is assessing the requirements for growing plants that are cultivated, or some soil properties, and a location that has a negative influence against the plant. The second phase is to identify the limitation that has the desired traits, but without the unwanted properties [4]. The land is a physical environment that consists of several items such as land, water, topography, and climate [5]. The land has a function as a habitat for agricultural plant growth and plantations. Based on the results of the measurements obtained some indicators such as the hydrotopographic zone, the organic layer depth, cation exchange capacity, ash content value, content of pyrite, drainability, and salinity.

\subsubsection{Hydrotopographic Zone}

Barambai unit has 3 (three) hydrotopographic zones, categories A, B, and C (Fig. 2). Land with the category $\mathrm{A}$ is affected by the tide at least 4 or 5 times in a 14-day cycle full moon tide, both in the wet season and dry season. The land is mostly located in the lowland area or close to the river. Category B is affected by the tide at least 4 or 5 times in a 14-day cycle full moon-tide but only in the rainy season. Category $\mathrm{C}$ could not be affected regularly by the tide, but groundwater can still be influenced [6].
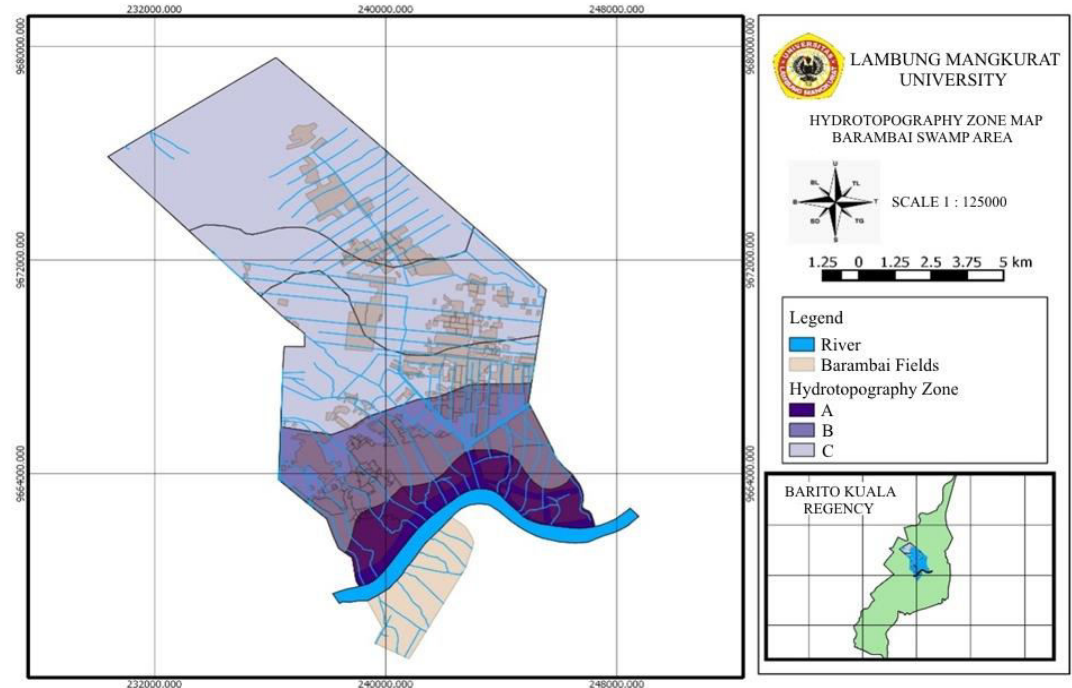

Fig. 2. Barambai Hydrotopographic Zone Map 


\subsubsection{Organic Layer Depth}

The results of five observation points obtained organic layer depth that reaches more than 2 $m$ (Fig. 3). The organic material in the soil shows the activities of organisms and chemical physics processes in the soil [5]. The existence of a land use through tillage and fertilization affecting the existence of the content of organic matter in the soil. The content of organic matter in the soil also shows the process of respiration, denitrification, and absorption of phosphorus in the soil. Therefore, the organic materials have an extremely important role in supporting the land capability in generating high productivity [7-9].
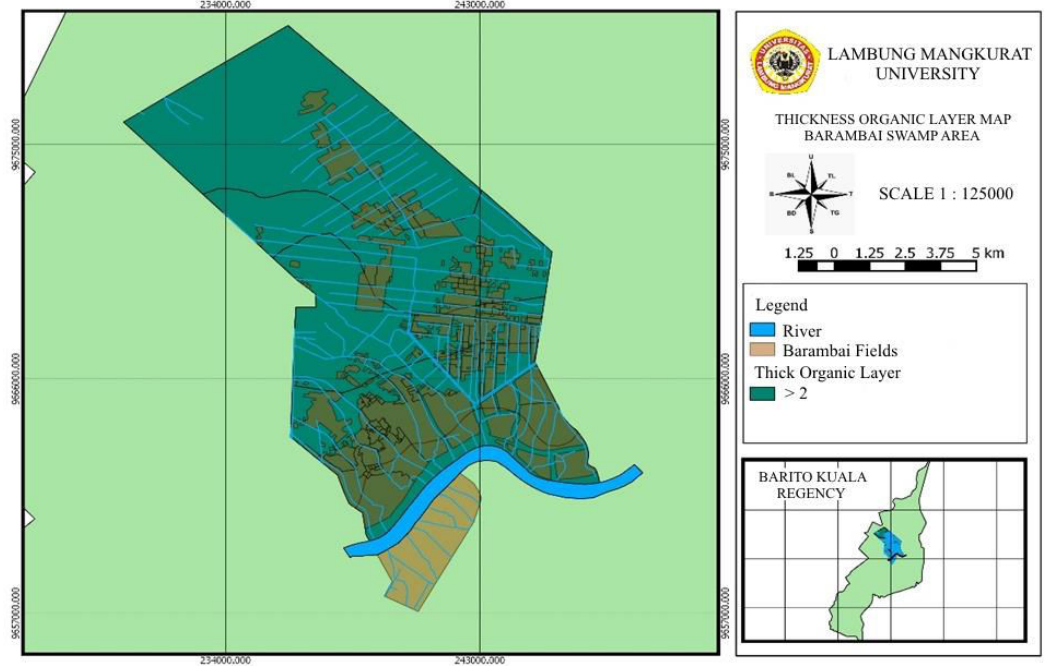

Fig. 3. Thickness Organic Layer Map

\subsubsection{The Value of The Cation Exchange Capacity}

Based on laboratory test data, the value of the cation exchange capacity of soils has moderate to high value between 23.52-34.94 me. $100 \mathrm{~g}^{-1}$ (Fig. 4).
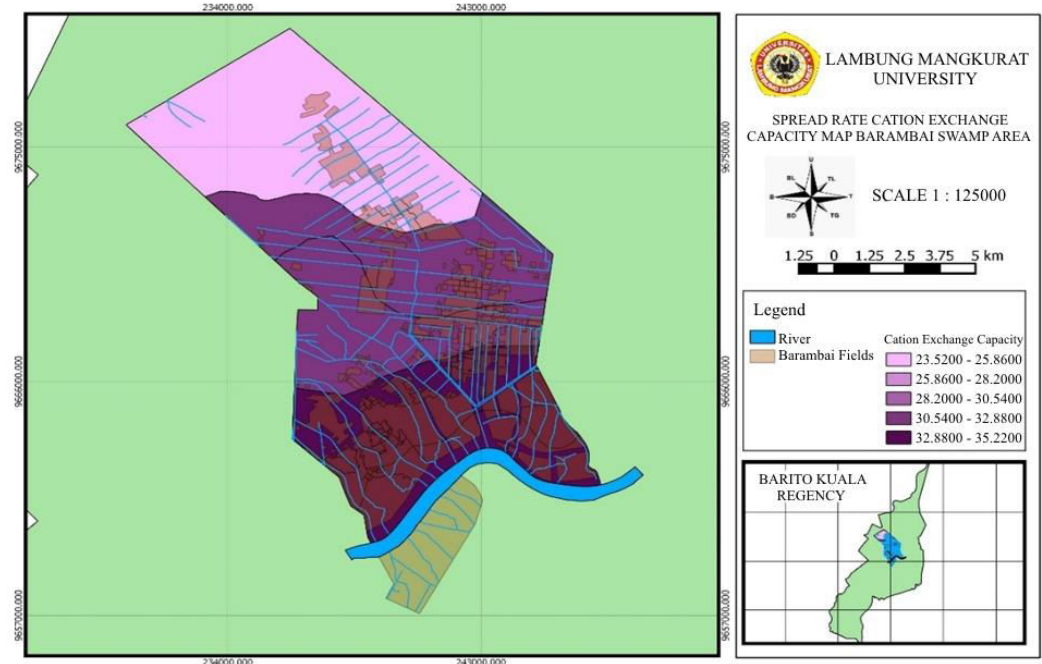

Fig. 4. Map Of The Distribution Of The Value Of The Cation Exchange Capacity 
Soil that has a high cation exchange capacity due to soil sample has a high content of organic material. The existence of the nature of the cation exchange capacity of the soil and mineral weathering affects the behaviour of potassium in the soil. As a result, the element potassium does not pose a problem of environmental externalities, if these elements leave the system ground [5].

\subsubsection{Ash Content Value}

Based on laboratory test data, the value of ash level between 51.69-31.15\% (Fig. 5). The measurement is affected by the condition of carbon stored in the soil. Carbon included in plant nutrition as an important element which is able to be provided by the ground. Generally, carbon drawing up $45-50 \%$ of dry weight biomass[10]. In the soil carbon can be stored in the form of minerals, so it may experience increased or decreased depending on the previous conditions and processing conditions.
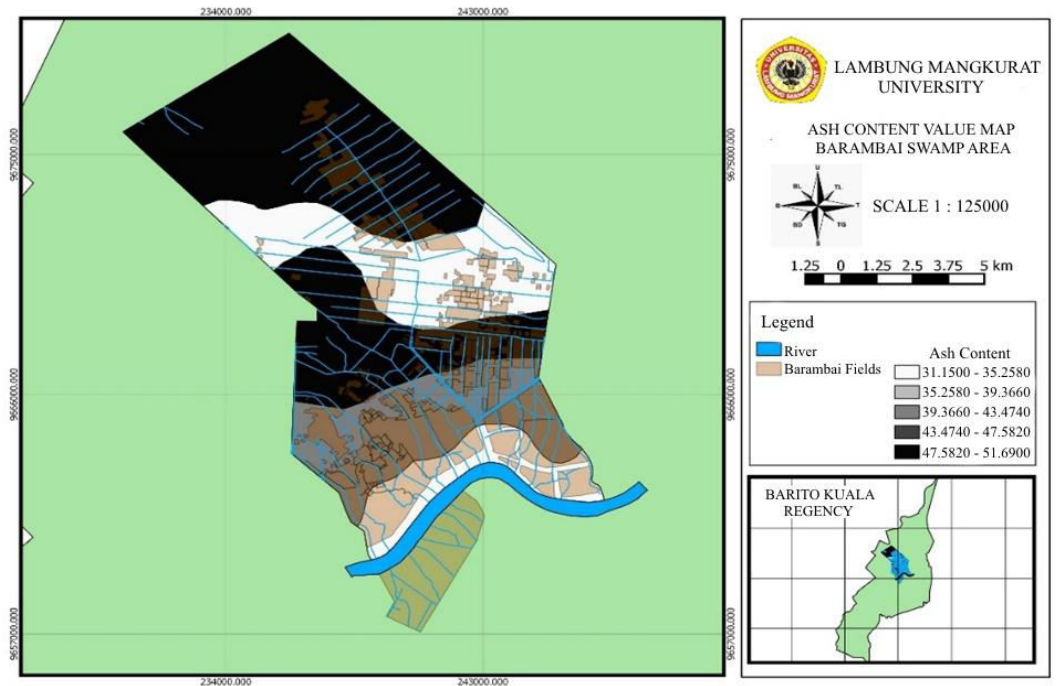

Fig. 5. Ash Content Value Map

\subsubsection{Pyrite Layer}

Pyrite layer is found below $30 \mathrm{~cm}$ (fig. 5), which entered the harmful criteria for plant growth. The depth of the pyrite layer $20-50 \mathrm{~cm}$ is still safe for the plant. The soil need to be flushed (when it rains or during high tide). The depth of groundwater must be maintained for a minimum of $30-40 \mathrm{~cm}$ from the surface ground level so that the pyrite remains submerged[6]. 

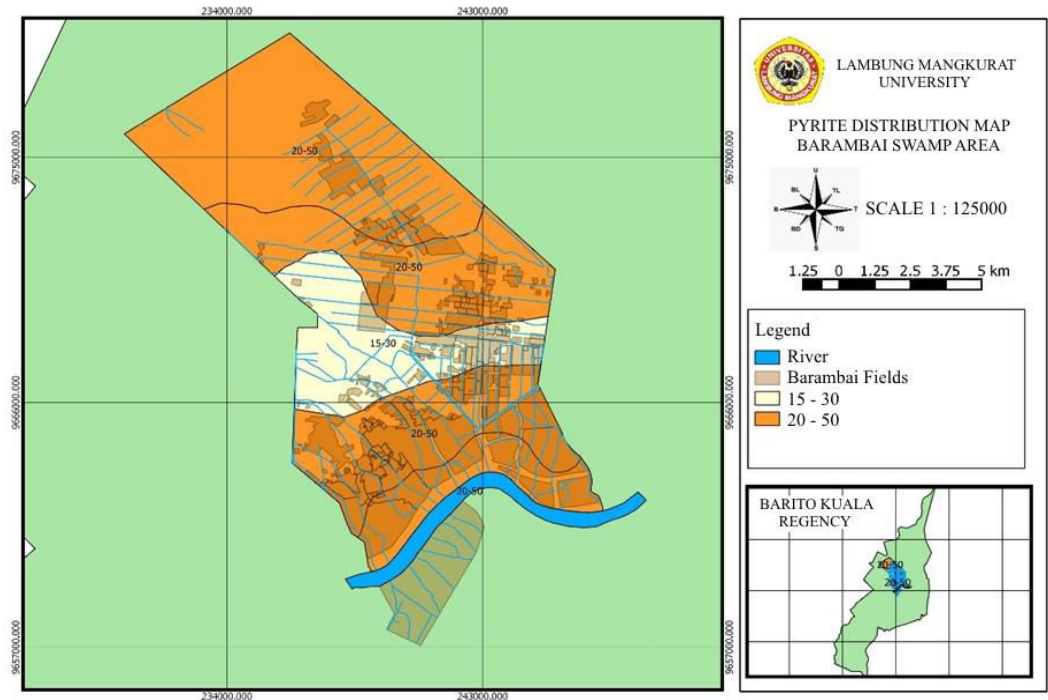

Fig. 6. Pyrite Distribution Map

\subsubsection{Drainability}

The depth of the groundwater greatly determines the agricultural development in the area of the tidal swamp.

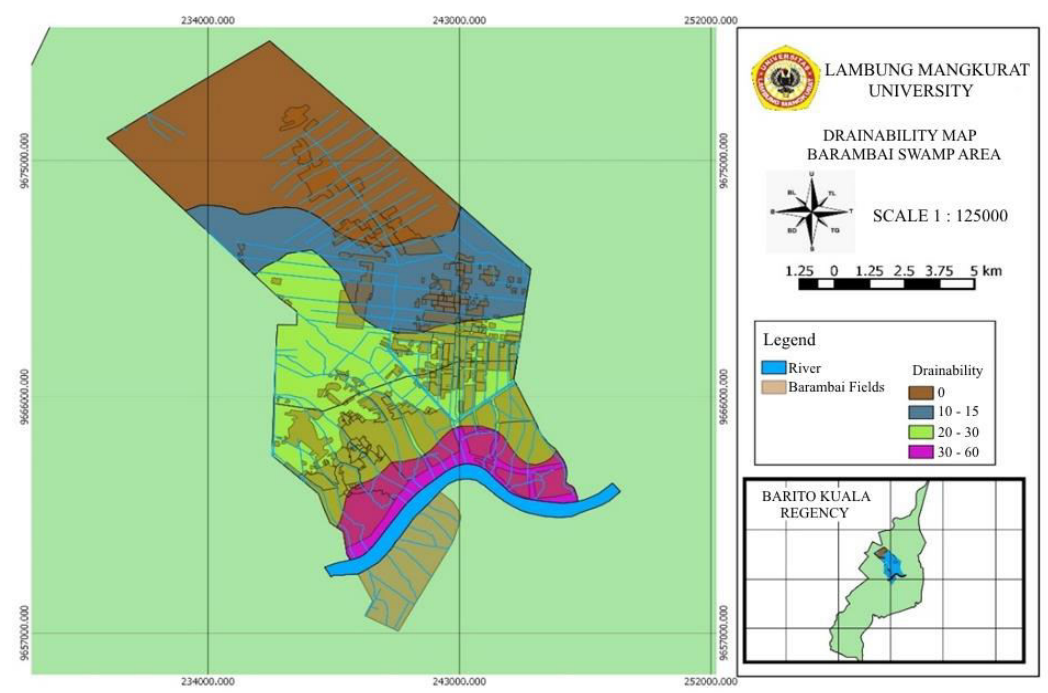

Fig. 7. Drainability Map 
This condition is associated with the drainage system of land, so the depth of the groundwater and inundation were main factors for assessing the potential of a land drainability. The depth of the groundwater in the study area is affected by tidal fluctuations (Fig. 7).

\subsubsection{Salinity}

Based on the salinity analysis results, Barambai reclamation unit has salinity level from 0.038 to 0.364 (Table 1). The spatial basis can be shown in Fig. 8.

Table 1. The Results Conversion of The Value Conductivity to Salinity

\begin{tabular}{ccccccc}
\hline Sample & $\mathrm{pH}$ & $\begin{array}{c}\text { TDS } \\
(\mathrm{ppm})\end{array}$ & $\begin{array}{c}\text { Temperature } \\
\left({ }^{\circ} \mathrm{C}\right)\end{array}$ & $\begin{array}{c}\text { Conductivity } \\
(\mu \mathrm{S} / \mathrm{cm})\end{array}$ & Salinity & Description \\
\hline 1 & 4.63 & 131 & 29 & 254 & 0,114 & salinity \\
2 & 6.45 & 76 & 29.1 & 145 & 0,068 & salinity \\
3 & 3.89 & 414 & 28.9 & 792 & 0,364 & salinity \\
4 & 4.24 & 77 & 29 & 139,1 & 0,065 & salinity \\
5 & 6.14 & 54 & 28.9 & 72,5 & 0,038 & No salinity \\
\hline
\end{tabular}

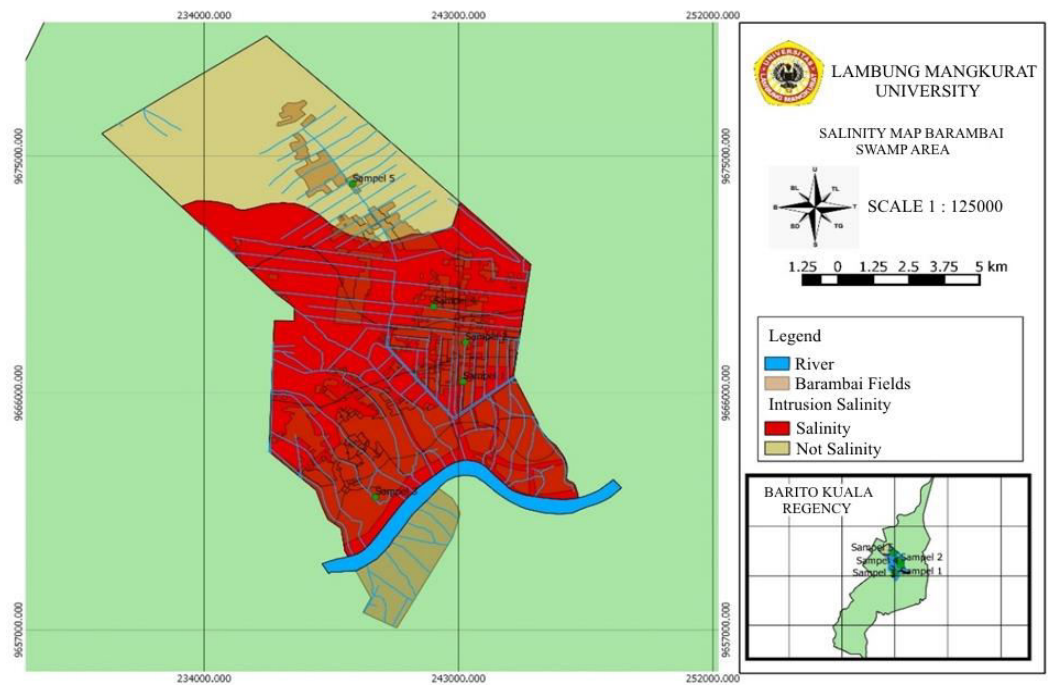

Fig. 8. Salinity Map Barambai

\subsection{Potential and strategy}

Evaluation of land characteristics and analysis of land units show the main constraints or limiting factor which is the availability of water especially during the dry season and the excess water in the rainy season.

The result of land unit suitability in Barambai unit shows that the land was good (S1 and S2) for paddy plant (rainfed or irrigated). All types the proposed plant except for the paddy with tidal irrigation fit into the not appropriate criteria (NA) (Fig. 9). But in terms of hydrotopography, land in the irrigated area still has potential with the limitation of the salinity and brackish water problem. 


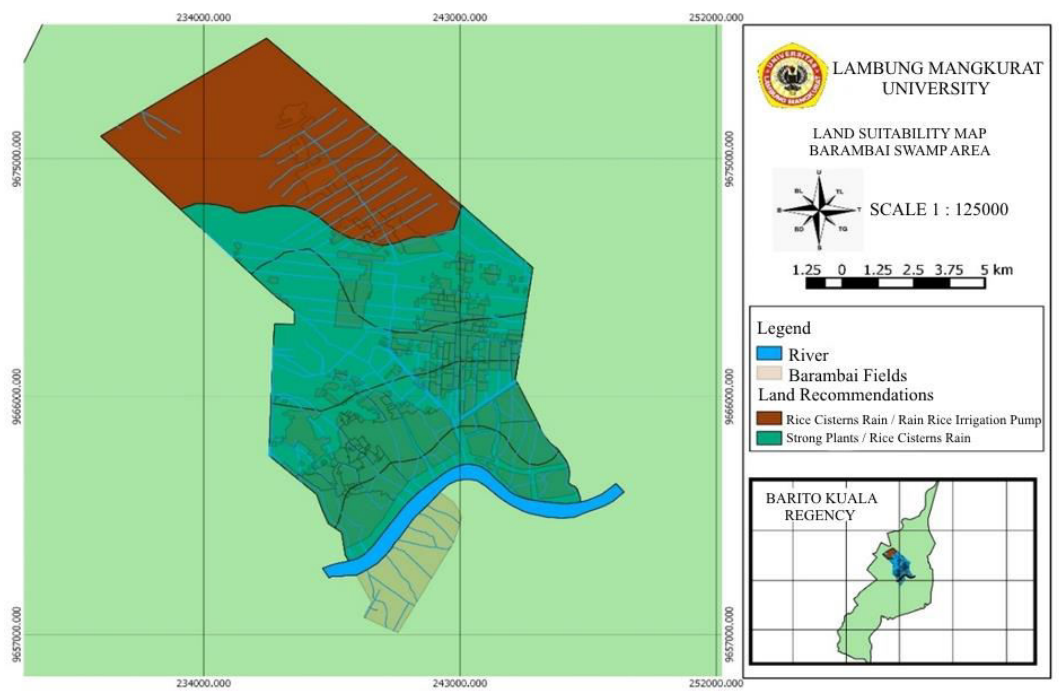

Fig. 9. Swampland Suitability Map Barambai

The utilization of land with proper water management, both at the level of the macro and micro-water management system will increase the agricultural land suitability, thus support the production of commodities that are developed as an ongoing basis. Related to this, the proposed land utilization need to review the following aspects: land use typology, land suitability, land use, and crop patterns. To improve soil fertility in tidal swampland the fertilizer management needs to be administered by the combination of Boric fertilizer with the composition of 100-150 kg. acres ${ }^{-1}$, two or three times a year starting from the second year after planting $[11,12]$.

\section{Conclusion}

The results of land agricultural suitability analysis in Barambai tidal swampland reclamation unit stated that the land is most suitable for paddy plant (S1 and S2 criteria). In general, the condition of soil fertility in Barambai unit is low to moderate, the $\mathrm{pH}$ of the soil is acid to very acid, and relatively high pyrite hazards. The study recommends the improvements in water management system, land use, crop patterns, and the proper fertilization.

\section{References}

1. Riduan, R. Evaluation of Dissolved Iron Transport in Primary and Secondary Channels of Terantang Reclamation Unit Using OTEQ Model (One-Dimensional Transport with Equilibrium Chemistry). (Lambung Mangkurat University, Banjarbaru, 2016).

2. Lufti, C. P., Riduan, R. \& Nilawati, R. I. N. Suitability Evaluation of Land Use for Citrus Plants in Alalak and Mandastana Districts, Barito Kuala. Jernih: Final Project Journal for Environmental Engineering Students 1 (2018).

3. Rayes, M. L. Land Resources Inventory Method. (Andy, 2007).

4. Tinker, P. B. Soil Requirement of the Soil Palm. (Elsevier Scientific Publishing Company, 1982). 
5. Prasetia, H. \& Annisa, N. Land Suitability Analysis of Smallholder Oil Palm Plantation and Barrier Factor For Oil Palm Plants in Seruyan Regency, Central Kalimantan. Jukung Jurnal Teknik Lingkungan 3, 35-40 (2017).

6. Riduan, R. \& Utomo, B. Toxic Substance Transport Numerical Model in Terantang Reclamation Channel. Jukung (Jurnal Teknik Lingkungan) 2 (2016).

7. Grandy, S., Strickland, M., L. Lauber, C., A. Bradford, M. \& Fierer, N. The influence of microbial communities, management, and soil texture on soil organic matter chemistry. Vol. 150 (2009).

8. Brady, N. C. \& Weil, R. R. The nature and properties of soils. (Prentice Hall International, 1996).

9. Bruland, G. \& Richardson, C. Comparison of Soil Organic Matter in Created, Restored and Paired Natural Wetlands in North Carolina. Vol. 14 (2006).

10. Whitmore, T. C. Tropical Rain Forests of the Far East. (Oxford: Clarendon Press, 1985).

11. Prasetia, H. Optimization Of The Management Of Sustainable Palm Oil Plantations (A Case Study In The District Of Seruyan, Central Kalimantan), (2016).

12. Ng, S. K., Tan, Y. P., Chan, E. \& S.P.Cheong. Nutritional Complexes Of Oil Palms Planted On Peat Soil In Malaysia. II. Preliminary Results Of Copper Sulphate Treatments. Oleagineux 29, 445-456 (1974). 